\title{
PENGARUH GOOD CORPORATE GOVERNANCE TERHADAP KINERJA KEUANGAN DENGAN MANAJEMEN LABA SEBAGAI VARIABEL INTERVENING PADA PERUSAHAAN PERBANKAN YANG TERDAFTAR DI BURSA EFEK INDONESIA
}

\author{
Vella Melania \\ Program Studi Manajemen, STIE “KBP” Padang \\ Email : vellamelania21@gmail.com
}

\begin{abstract}
Increasing problem credit, resulted in decline commodity price and value changes. The purpose of this research to verify the influence of good corporate governance (board of directors and audit committe) to financial performance with earning management as intervening variabel. The sample of this research are 14 banking companies registered in BEI period 2012-2016. This research use regression analysis method with intervening variabel and path analysis for mediation variabel. The result of research showed that the board of directors had a positive and significant effect to financial performance, the audit committee had no significant positive effect to financial performance, the board of directors had no significant negative effect to earnings management, the audit committee had no significant negative effect to earnings management, and earning management had no significant positive effect to financial performance. In Sobel test, earnings management doesn't mediate board of director relationship with financial perfomance and earnings management doesn't mediate audit committee with financial performance.
\end{abstract}

Keywords : Board of Directors, Audit Committee, Earning Management, Financial Performance

\begin{abstract}
ABSTRAK
Meningkatnya kredit bermasalah pada industri pebankan mengakibatkan penurunan harga komoditas dan perubahan nilai. Penelitian ini bertujuan untuk menguji pengaruh good corporate governance (dewan direksi dan komite audit) terhadap kinerja keuangan dengan manajemen laba sebagai variabel intervening. Sampel penelitian ini sebanyak 14 Perusahaan perbankan yang terdaftar di BEI periode 2012-2016. Penelitian ini menggunakan metode analisis regresi dengan variabel intervening dan analisis jalur untuk variabel mediasi. Hasil penelitian menunjukan bahwa dewan direksi berpengaruh positif dan signifikan terhadap kinerja keuangan, Komite audit berpengaruh positif tidak signifikan terhadap kinerja keuangan, dewan direksi berpengaruh negatif tidak signifikan terhadap manajemen laba, komite audit berpengaruh negatif tidak signifikan terhadap manajemen laba, dan manajemen laba berpengaruh positif tidak signifikan terhadap kinerja keuangan. Pada Sobel test, manajemen laba tidak memdiasi hubungan dewan direksi dengan kinerja keuangan, dan manajemen laba tidak memediasi komite audit dengan kinerja keuangan.
\end{abstract}

Kata Kunci :Dewan Direksi, Komite Audit, Manajemen Laba, Kinerja Keuangan 


\section{PENDAHULUAN}

Kinerja keuangan merupakan indikator yang dapat digunakan dalam melihat kondisi keuangan dalam suatu perusahaan. Kinerja keuangan dijadikan media untuk mengukur kesehatan suatu perusahaan. Kinerja keuangan perusahaan adalah hasil dari banyak keputusan individual yang dibuat secara kontiniu oleh manajemen (Danil \& Yusra, 2019; Hadya, 2013). Kinerja keuangan industri perbankan sangat penting perannya karena bank berhubungan secara langsung dengan kepercayaan. Selain itu kinerja keuangan perbankan ini akan meningkatkan nilai jual dan nama baik perusahaan. Untuk mengambil sebuah keputusan investasi kinerja keuangan ini akan selalu dibutuhkan nasabah dan juga investor, dimana peran dari kinerja keuangan ini sangat besar pada keputusan tersebut.

Return on Asset (ROA) merupakan suatu pengukuran kinerja perusahaan yang menunjukan kemampuan dari perusahaan dalam menghasilkan laba dalam rangka penggunaan aset yang dimilikinya (Hadya, Begawati, \& Yusra, 2017; Putra \& Yusra, 2019; Yusra, 2016). Laporan keuangan adalah informasi yang dipublikasikan suatu perusahan tidak terlepas dari tindakan manajemen laba yang dilakukan manajer perusahaan untuk meningkatkan nama baik perusahaan.

Pada tahun 2017 ini kinerja yang diberikan oleh sektor perbankan masih kurang baik, dimana sektor ini masih dihadapkan pada kualitas aset yang kurang baik. Kualitas aset yang kurang baik terlihat pada perkembangan aktiva produktif yang sedang bermasalah, hal ini terjadi karena perbankan dengan gencar untuk menyalurkan kredit kepasaran sehingga kredit macet atau kredit bermasalah (Non Perfoming Loan/NPL) terjadi dan akan menjadi perhatian khusus (special mention) bagi perbankan. Non perfoming loan (NPL) dan Special mention yang berada pada kategori 2 sampai 5 dalam kredit mengakibatkan penurunan harga komoditas dan efek value change (perubahan nilai).

Kinerja dari sebuah perusahaan juga dapat dipengaruhi oleh bagaimana sistem pengelolaan yang diterapkan perusahaan tersebut, bentuk dari pengelolaan ini disebut sebagai GCG atau tata kelola dari perusahaan (Good Corporate Governance) (Hadya \& Susanto, 2018). Good Corporate Governance adalah hal yang dapat dimanfaatkan oleh pemakai laporan keuangan tersebut dalam mengambil keputusan karena pinsip yang terkandung dalam GCG adalah transparansi dan akuntabilitas, serta penyajian informasi yang lengkap dan berkualitas(Utomo, 2014). GCG berkaitan dengan kepercayaan investor kepada para manajer, dimana mereka percaya bahwa manajer akan mampu memberikan keuntungan kepada mereka atas dana atau modal yang telah dinvestasikannya atau ditanamkan investor (Widyati, 2013). Ada tujuh mekanisme dalam mengukur corporate governance yaitu kepemilikan institusional, kepemilikan manajerial, dewan komisaris, dewan direksi, dewan komisaris independen, ukuran perusahaan dan komite audit.

Direksi merupakan orang yang mempunyai peranan penting dalam menentukan pertumbuhan perusahaan. Prinsip yang harus dipenuhi agar tugas direksi berjalan dengan efektif adalah jumlah direksi yang harus mengambil keputusan secara efektif, tepat, cepat dan dapat bertindak independen (Widyati, 2013). Komite audit didefenisikan sebagai komite yang bekerja independen dan profesional. Komite audit dibentuk oleh dewan komisaris sebagai pembantu atau orang yang memerkuat fungsi dari dewan komisaris serta membantu dewan komisaris menjalankan fungsi dari 
pengawasan ataupun pelaporan keuangan, implementasi Good Corporate Governance dalam perusahaan dan pelaksanaan audit serta manajemen resiko perusahaan.

Komite audit (Audit Comitte) memberikan suatu pandangan tentang masalah akuntansi, laporan keuangan dan penjelasannya, sistem pengawasan internal serta auditor independen. Tanggung jawab komite audit secara umum dalam bidang Financial Reporting adalah memastikan bahwa laporan keuangan terlah menggambarkan keadaan perusahaan secara wajar mengenai kondisi keuangan, hasil usaha, dan komitmen jangka panjang (Dewi, 2012).

Salah satu tujuan dari GCG adalah mengurangi adanya tindakan atau praktek manajemen laba yang sering dilakukan manajer suatu perusahaan. Sehingga dengan adanya sistem pengawasan serta pengendalian sebagai prinsip dasar GCG munculah harapan - harapan menurunnya tindakan atau praktek manajemen laba pada penerapan GCG ini terutama implementasi dalam prinsip-prinsip yang ada. Manajemen laba diukur dengan metode akuntansi berbasis akrual. Metode ini digunakan untuk mengidentifikasi manajemen laba dengan menggunakan komponen kas dam akrual dalam laporan keuangan (Sulistyanto, 2014).

\section{Teori Keagenan (Agency Theory)}

Perspektif hubungan keagenan merupakan dasar yang digunakan untukmemahami corporate governance(Ujiyantho \& Bambang, 2007). Karena teori keagenan merupakan konsep dasar dari corporate governance, berfungsi sebagai alat dalam memberikan keyakinan kepada para investor bahwa mereka akan menerima return atau pengebalian atas dana yang diinvestasikan. Corporate governance merupakan keyakinan yang dimiliki investor tentang perusahaan yang mampu memberikan keuntungan kepada mereka, selain itu investor yakin bahwa manajer perusahaan tidak akan menggelapkan maupun mencuri atau meninvestasikan dana yang telah ditanamkan investor kepada proyek yang tidak menguntungkan dan $\mathrm{CG}$ berkaitan juga dengan bagaimana para investor mengontrol para manajer perusahaan (Sekaredi, 2011).

Teori keagenan analoginya adalah seperti antara pemilik perusahaan dengan manajemen perusahaan itu. Aksi yang dilakukan oleh para agen, sementara itu fungsi utilitas dalam kepentingan akhir adalah milik prinsipal. Teori keagenan sangat berkaitan dengan peranan penting akuntansi dalam menyediakan informasi untuk pengambilan keputusan. Peran ini diasosiasikan dengan peran pengurusan (stewardship) akuntansi, di mana seorang agen melapor pada prinsipal tentang apa yang terjadi (Afnan, 2014).

Hubungan keagenan terjadi pada saat satu individu atau lebih yang disebut dengan prinsipal menyewa individu lain atau organisasi lain, yang disebut dengan agen, untuk melakukan jasa dan mendelegasikan kewenangan dalam membuat keputusan pada agen tersebut (Widiawati, 2011). Hubungan antara prinsipal dan agen ini seharusnya terjalin hubungan yang saling menguntungkan antara satu pihak dengan pihak yang lain. Namun hal yang sering terjadi adalah munculnya permasalah agensi (agency problem) antara pemilik dan pengelola perusahaan. 


\section{Dewan Direksi dan Kinerja Keuangan}

Dewan direksi dalam perusahaan akan menetukan kebijakan yang akan diambil atau strategi perusahaan tersebut secara jangka panjang maupun jangka pendek (Lestari, 2011). Agar pelaksanaan tugas direksi dapat berjalan secara efektif, salah satu prinsip yang perlu dipenuhi adalah komposisi direksi harus sedemikian rupa sehingga memungkinkan pengambilan keputusan secara tepat, cepat dan efektif, serta dapat bertindak independen (Widyati, 2013). Keputusan yang diambil manajer berkaitan dengan kinerja keuangan perusahaan tersebut, dimana dari keputusan-keputusan yang dilakukan dapat dilihat bagaimana kinerja perusahaan pada saat itu.

Penelitian yang dilakukan oleh Dewi (2012) yang meneliti pengaruh GCG terhadap kinerja keuangan dengan variabel serupa membuktikan bahwa dewan direksi mempunyai pengaruh yang positif dan signifikan terhadap kinerja keuangan. Penelitian lain yang dilakukan oleh Noviawan (2013) yang mengukur pengaruh mekanisme Corporate Governance (CG) dan struktur kepemilikan terhadap kinerja keuangan, dengan menggunakan alat analisis regresi linear berganda membuktikan bahwa dewan direksi berpengaruh terhadap kinerja keuangan. Kemudian penelitian yang dilakukan oleh Widyati (2013) menemukan bahwa secara simultan dewan direksi dan proksi lainnya memberikan pengaruh yang signifikan terhadap kinerja keuangan sedang secara parsia dewan direksi berpengaruh tidak signifikan terhadap kinerja keuangan.

$\mathrm{H}_{1}$ : Diduga dewan direksi berpengaruh positif secara signifikan terhadap kinerja keuangan

\section{Komite Audit dan Kinerja Keuangan}

Berdasarkan Kep-315/BEJ/06200 komite audit dibentuk oleh dewan komisaris perusahaan tercatat. Anggota komite audit diangkat dan diberhentikan oleh dewan komisaris perusahaan tercatat (Widiawati, 2011). Komite audit bertugas melakukan pengawasan dalam meningkatkan efektifitas untuk menciptakan keterbukaan dan pelaporan keuangan yang berkualitas, ketaatan terhadap peraturan perundang-undangan yang berlaku, dan pengawasan internal yang memadai. Kaitan dari komite audit dengan kinerja keuangan terlihat dari fungsi pengawasan yang dilakukan komite audit. Dimana dari laporan keuangan yang dibuat manajer dan dewan komisaris komit audit mempunyai tugas independen untuk memastikan laporan keuangan yang disusun bersih dan dapat dipertanggungjawabkan.

Penelitian yang dilakukan Widyati (2013) mengenai pengaruh indikator Good Corporate Governance (GCG) terhadap kinerja keuangan menemukan hasil analisis yang membuktikan bahwa pengaruhnya secara parsial dilihat dari nilai t signifikannya komite audit mempunyai pengaruh yang positif dan tidak signifikan terhadap kinerja keuangan. Penelitian yang dilakukan Kemudian penelitian Dwi Lestari (2011) juga menunjukan hasil yang berbeda dimana komite audit ini memberikan pengaruh yang positif dan juga signifikan terhadap kinerja keuangan. Laporan keuangan perusahaan akan lebih berkualitas dengan adanya komite audit dalam perusahaan dimana hal ini sesuai dengan tugas dan tanggung jawabnya dalam mengawasi laporan keuangan.

$\mathrm{H}_{2}$ : Diduga Komite Audit berpengaruh positif dan tidak signifikan terhadap kinerja keuangan 


\section{Dewan Direksi dan Manajemen Laba}

Manajemen laba secara umum diartikan sebagai upaya-upaya yang dilakukan manajer perusahaan dalam mengintervensi ataupun mempengaruhi informasi-informasi yang ada dalam laporan keuangan agar dapat mengelabui stakeholder yang ingin mengetahui bagaiman kinerja dan kondisi perusahaan tersebut. Dewan direksi merupakan organisasi yang menetukan kebijakan mana yang akan diambil perusahaan atau strategi yang akan diterapkan perusahaan baik itu secara jangka pendek maupun jangkan panjang.

Penelitian yang dilakukan Husni (2010) menunjukan bahwa dewan direksi mempunyai pengaruh terhadap manajemen laba. Kemudian penelitian yang dilakukan oleh Iqbal \& Fachriyah (2016) tentang Corporate Governance sebagai alat pereda praktek manajemen laba menunjukan bahwa secara parsial ukuran dewan direksi memiliki pengaruh yang positif serta signifikan terhadap manajemen laba.

$\mathrm{H}_{3}$ : Diduga dewan direksi berpengaruh positif dan signifikan terhadap manajemen laba

\section{Komite Audit dan Manajemen Laba}

Mekanisme good corporate governance (kepemilikan institusional, kepemilikan manajerial, proporsi dewan komisaris dan komite audit) memiliki kemampuan dalam menghasilkan laba. Dengan menerapka good corporate governance diharapkan dapat mengurangi dorongan untuk melakukan tindakan manipulasi oleh manajer, sehingga kinerja yang dilaporkan merefleksikan keadaan ekonomi bersangkutan.

Kusumaningtyas (2012) melakukan penelitian tentang pengaruh independensi komite audit terhadap manajemen laba menemukan hasil analisis bahwa komite audit mempunyai pengaruh yang negatif terhadap manajemen laba. Kemudian penelitian yang dilakukan Agustia (2013) menemukan hasil bahwa komite audit tidak mempunyai pengaruh yang signifikan terhadap manajemen laba.

$\mathrm{H}_{4}$ : Diduga Komite audit berpengaruh negatif dan tidak signifikan terhadap manajemen laba.

\section{Manajemen Laba dan Kinerja Keuangan}

Laba merupakan alat ukur dalam yang digunakan manajemen perusahaan dalam mengukur kinerja dari manajemen tersebut pada periode tertentu. Laba disini menjadi perhatian dari pihak-pihak tertentu dalam menaksir kinerja serta pertanggungjawaban manajemen dalam proses pengelolaan sumber daya yang terlah dipercayakan pada manajemen tersebut, serta laba juga dapat dipergunakan untuk memperkirakan prospek untuk masa mendatang (Sriwedari, 2012).

Penelitian Ujiyantho, Arief\& Agus (2007) menunjukan bahwa manajemen laba tidak mempunyai dampak yang signifikan terhadap kinerja keuangan. Hasil ini juga didukung/diperkuat oleh penelitian Sriwedari (2012) mengenai mekanisme Good Corporate Governance, manajemen laba, dan kinerja keuangan dengan menggunakan objek pada perusahaan manufkatur dibursa efek indonesia menemukan hasil bahwa manajemen laba berpengaruh negatif namun tidak signifikan trehadap kinerja keuangan. 
$\mathrm{H}_{5}$ : Diduga Manajemen laba berpengaruh negatif dan tidak signifikan terhadap kinerja keuangan

\section{Dewan Direksi, Manajemen Laba dan Kinerja Keuangan}

Good corporate governance diajukan dan diharapkan mampu memberikan peningkatan terhadap kinerja perusahaan melalui monitoring kinerja manajemen serta menjamin akuntabilitas manajemen terhadap stakeholder yang mendasarkan pada kerangka peraturan yang berlaku. Pihak - pihak yang mempunyai kepentingan tertentu akan melakukan penyusunan laporan keuangan yang sesuai dengan keinginannya. Hal ini sering terjadi dan dianggap membudaya dalam pengelolaan suatu perusahaan. hal ini dikarenakan pengawasan yang masih kurang optimal dilakukan perusahaan serta aturan dan standar akuntansi, auditing serta prinsip transparansi yang masih lemah penerapannya. Oleh karena itu pengawasan dan pengendalian yang baik perlu dilakukan untuk menghambat terjadinya penyelewengan. dengan demikian perlu adanya pihak yang berperan untuk mengendalikan serta mengawasi tindakan dan keputusan manajer perusahaan yang pada akhirnya pengelolaan perusahaan berjalan sehat, bersih dan bertanggung jawab.

Penelitian yang dilakukan Ujiyantho, Arief\& Agus (2007) tentang Good Corporate Governance, manajemen laba, dan kinerja keuangan mebuktikan dengan hasil analisisnya bahwa secara simultan variabel-variabel GCG teruji mempunyai pengaruh yang signfikan terhadap manajemen laba. Sedangkan dalam pengujian berikutnya manajemen laba tidak mempunyai pengaruh terhadap kinerja keuangan.

$\mathrm{H}_{6}$ : Manajemen Laba memediasi hubungan antara dewan direksi dengan kinerja keuangan

\section{Komite Audit, Manajemen Laba, dan Kinerja Keuangan}

Penerapan prinsip GCG membuat perusahaan akan mempunyai komite audit dan komisaris independen sebagai pihak yang melakukan pengawasan serta pengendalian dalam menciptakan keadilan, transparansi, akuntabilitas dan responsibilitas. Proporsi independensi komite audit mempunyai hubungan positif antara komite audit dengan berkurangnya tekanan manajer terhadap komite audit dalam penyusunan laporan keuangan. Selain itu kompetensi dari komite audit mempunyai hubungan dengan menurunya kemungkinan dilakukannya manajemen laba. Artinya, semakin kompeten komite audit akan semakin mengurangi kemungkinan aktivitas manajemn laba (Sulistyanto, 2014).

Penelitian yang dilakukan oleh Sriwedari (2012) mengenai mekanisme good corporate governance, manajemen laba dan kinerja keuangan yang menggunakan komite audit sebagai salah satu variabel dalam penelitiannya menemukukan hasil bahwa komite audit memberikan pengaruh yang positif dan tidak signifikan terhadap manajemen laba, serta manajemen laba memberikan pengaruh yang negatif dan juga tidak signifikan terhadap kinerja keuangan.

$\mathrm{H}_{7}$ : Manajemen laba memediasi hubungan antara komite audit dengan kinerja keuangan 


\section{METODE PENELITIAN}

Jenis penelitian ini adalah penelitian kuantitaif yaitu didasrkan pada angka-angka. Objek penelitian ini Perusahaan Perbankan yang terdaftar di Bursa Efek Indonesia. Yang menjadi populasi dalam penelitian ini semua perusahaan perbankan yang terdaftar di Bursa Efek Indonesia pada periode 2012-2016 sebanyak 40 perusahaan. Tekhnik pengambilan sampel yang digunakan adala teknik purposive sampling purposive sampling. Dari teknik tersebut sampel penelitian yang memenuhi keseluruhan kriterianya sebanyak 14 perusahaan perbankan.Jenis data dalam penelitian ini data kuantitatif yang bersumber dari data sekunder berupa laporan keuangan dari perusahaan sampel yang dipublikasikan pada website Bursa Efek Indonesia www.idx.co.id

\section{Defenisi Operasional Variabel}

\begin{tabular}{|c|c|c|}
\hline Variabel & Defenisi & Proxy (Indikator) \\
\hline Dewan Direksi & $\begin{array}{l}\text { Dewan direksi adalah anggota } \\
\text { dewan yang bertanggung jawab } \\
\text { kinerja dan manajemen } \\
\text { perusahaan. }\end{array}$ & $\begin{array}{l}\text { jumlah keseluruhan anggota } \\
\text { dewan direksi dalam } \\
\text { perusahaan }\end{array}$ \\
\hline Komite Audit & $\begin{array}{l}\text { Komite audit bertanggung jawab } \\
\text { untuk mengawasi laporan } \\
\text { keuangan, mengawasi audit } \\
\text { eksternal, dan mengawasi sistem } \\
\text { pengendalian internaldan } \\
\text { mengurangi opportunistic } \\
\text { manajemen yang melakukan } \\
\text { manajemen laba. }\end{array}$ & $\begin{array}{l}\text { jumlah keseluruhan anggota } \\
\text { komite audit dalam } \\
\text { perusahaan }\end{array}$ \\
\hline Kinerja Keuangan & $\begin{array}{l}\text { Kinerja keuangan alat ukur untuk } \\
\text { melihat kemampuan dari } \\
\text { perusahaan. Kinerja keuangan } \\
\text { diukur dengan menggunakan rasio } \\
\text { Return on Assets (ROA). ROA } \\
\text { merupakan rasio yang digunakan } \\
\text { untuk mengukur kemampuan } \\
\text { manajemen bank dalam } \\
\text { memperoleh keuntungan (laba) } \\
\text { secara keseluruhan dan } \\
\text { menunjukan tingkat efisiensi } \\
\text { kinerja. }\end{array}$ & $R O A=\frac{\text { Laba Bersih }}{\text { Rata }- \text { rata Asset }}$ \\
\hline Manajemen Laba & $\begin{array}{l}\text { Manajemen laba diukur dengan } \\
\text { model akuntansi berbasis akrual. } \\
\text { Model ini menggunakan } \\
\text { komponen kas dan akrual dalam } \\
\text { laporan keuangan. }\end{array}$ & $\mathrm{TAC}_{\mathrm{t}}=\mathrm{NI}_{\mathrm{t}}-\mathrm{CFO}_{\mathrm{t}}$ \\
\hline
\end{tabular}




\section{Teknik Analisis Data}

1. Analisis Statistik Deskriptif

Statistik deskriptif berfungsi untuk memberikan gambaran atau mendeskripsikan obyek yang akan diteliti melalui data atau sampel sebagaimana adanya, dan tidak melakukan analisis maupun membuat kesimpulan yang berlaku untuk umum (Sugiyono, 2015). Statistik deskriptif disini menggambarkan nilai rata-rata, maksimal, miniman dan nilai standar deviasi dari data sampel.

\section{Uji Asumsi Klasik}

Uji asumsi klasik yang digunakan terdiri dari tiga pengujian yaitu uji normalitas untuk melihat apakah data yang digunakan sudah berdistri normal, uji multikolinearitas untuk melihat apakah terdapat korelasi antar variabel bebas, dan uji heteroskedastisitas untuk melihat apakah terdapat ketidaksamaan variance dari residual satu pengamatan ke pengamatan lainnya (Ghozali, 2011).

3. Analisis Regresi dengan Variabel Intervening

Analisis regresi digunakan untuk meramalkan keadaan variabel dependen yang dipengaruhi oleh variabel independen. Dalam melakukan analisis regresi dengan variabel intervening digunakan dua model regresi. Adapun persamaan (model) yang digunakan dalam penelitian ini adalah :

Analisis Regresi berganda :

$$
\begin{gathered}
L N_{M L}=\alpha+\beta 1 L N_{D D}+\beta 2 L N_{K A}+e \\
K K=\alpha+\beta 1 D D+\beta 2 K A+\beta 3 M L+e
\end{gathered}
$$

Keterangan :

$$
\begin{aligned}
& \mathrm{KK}=\text { Kinerja Keuangan } \\
& \mathrm{ML}=\text { ManajemenLaba (Mediator) } \\
& \alpha \quad=\text { constanta } \\
& \beta \quad=\text { Koefisien regresi } \\
& \mathrm{DD}=\text { Jumlah Dewan Direksi } \\
& \mathrm{KA}=\text { Jumlah Komite Audit } \\
& \mathrm{Ln}=\text { Logaritma Natural } \\
& \mathrm{e}=\text { Error }
\end{aligned}
$$

4. Analisis Jalur

Analisis jalur digunakan untuk menguji pengaruh dari variabel intervening. Pada analisis jalur ini akan dibentuk sebuah diagram jalur yang menggambarkan pengaruh langsung dan pengaruh tidak langsung yang melalui variabel intervening.

\section{Uji Hipotesis}

- Uji T, uji ini digunakan untuk melihat pengaruh variabel independen terhadap variabel dependen sacara parsial.

- Uji Sobel, uji ini digunakan dalam melakukan pengujian hipotesis mediasi. Uji dilakukan dengan menguji kekuatan pengaruh tidak langsung variabel independen ke variabel dependen melalui variabel mediasi. 


\section{HASIL DAN PEMBAHASAN}

\section{Analisis statistik deskriptif}

Analisis statistik deskriptif dilakukan untuk memberikan gambaran atau deskripsi mengenai variabel penelitian meliputi : Jumlah sampel $(\mathrm{N})$, nilai terendah (minimum), nilai tertinggi (maxsimum), nilai rata-rata sampel (mean) dan standar deviasi pada setiap variabel.

Tabel 1

Deskripsi Statistik Variabel Penelitian

\begin{tabular}{lrrrrr}
\hline \multicolumn{1}{c}{ Variabel } & N & \multicolumn{1}{c}{ Mean } & Maksimum & Minimum & $\begin{array}{c}\text { Standar } \\
\text { deviasi }\end{array}$ \\
\hline Dewan Direksi & 70 & 8.5143 & 12.00 & 4.00 & 2.30150 \\
Komite Audit & 70 & 4.0857 & 8.00 & 3.00 & 1.29372 \\
Kinerja Keuangan & 70 & 1.0429 & 3.00 & 0.00 & .89176 \\
Manajemen Laba & 70 & -22.6692 & 800.84 & -857.93 & 255.91137 \\
\hline \multicolumn{2}{c}{ Sumber : Data Diolah } & & & &
\end{tabular}

Nilai rata-rata dewan direksi, komite audit, kinerja keuangan, dan manajemen laba dapat dilihat pada tabel diatas. Nilai terendah dan nilai tertinggi secara nilai keseluruhan dari masing-masing variabel juga dapat dilihat pada tabel diatas. Serta untuk standar deviasi dari masing-masing variabel juga disajikan pada tabel 1.

\section{Uji Asumsi Klasik}

1. Uji Normalitas

Uji normalitas digunakan untk melihat apakah dalam pengujian yang dilakukan data yang digunakan berdistribusi normal atau tidak, dengan taraf signifikansi besar dari $5 \%$.

\section{Tabel 2}

Hasil Uji Normalitas

\begin{tabular}{lcc}
\hline \hline & $\begin{array}{c}\text { Asymp. Sig. } \\
(\text { 2-tailed) }\end{array}$ & Keterangan \\
\hline $\mathrm{DD}, \mathrm{KA} \rightarrow \mathrm{ML}$ & 0.740 & Distribusi Normal \\
$\mathrm{DD}, \mathrm{KA}, \mathrm{ML} \rightarrow \mathrm{KK}$ & 0.857 & Distribusi Normal \\
\hline
\end{tabular}

Sumber: Data Diolah

Dari tabel Normalitas diatas dapat dilihat seluruh data analisis berdistribusi normal, karena nilai signifikan yang dihasilkan besar dari 5\% atau 0,05. 


\section{Uji Multikolinearitas}

Uji multikolinearitas digunakan untuk melihat apakah terdapat korelasi antar variabel bebas. Taraf pengambilan keputusan dalam uji ini adalah nilai VIF lebih kecil dari nilai 10 .

\section{Tabel 3}

Hasil Uji Multikolinearitas

\begin{tabular}{llccc}
\hline \multirow{2}{*}{ Model } & & \multicolumn{2}{c}{$\begin{array}{c}\text { Collinearity } \\
\text { Statistics }\end{array}$} & Keterangan \\
& & Tolerance & VIF & \\
\hline \hline \multirow{2}{*}{$\mathrm{DD}, \mathrm{KA} \rightarrow \mathrm{ML}$} & Dewan Direksi & 0.779 & 1.284 & Bebas \\
& Komite Audit & 0.779 & 1.284 & Multikolinearitas \\
& Dewan Direksi & 0.812 & 1.231 & Bebas \\
$\mathrm{DD}, \mathrm{KA}, \mathrm{ML} \rightarrow \mathrm{KK}$ & Komite Audit & 0.829 & 1.206 & Multikolinearitas \\
& Manajemen Laba & 0.978 & 1.023 & \\
\hline \hline
\end{tabular}

\section{Sumber: Data Diolah}

Dari tabel multikolinearitas diatas menunjukan seluruh variabel independen bebas gejala multikolinearitas, hal ini menunjukan tidak adanya korelasi yang terjadi antar variabel bebas tersebut.

3. Uji Heteroskedastisitas

Uji heteroskedastisitas untuk melihat apakah terdapat ketidaksamaan variance dari residual satu pengamatan ke pengamatan lainnya

\section{Tabel 4}

Hasil Uji Heteroskedastisitas

\begin{tabular}{llrl}
\hline \hline \multicolumn{1}{c}{ Model } & & Sig & Keterangan \\
\hline \multirow{2}{*}{$\mathrm{DD}, \mathrm{KA} \rightarrow \mathrm{ML}$} & Dewan Direksi & 0.134 & \\
& Komite Audit & 0.606 & Bebas Heteroskedastisitas \\
& Dewan Direksi & 0.057 & \\
$\mathrm{DD}, \mathrm{KA}, \mathrm{ML} \rightarrow \mathrm{KK}$ & Komite Audit & 0.611 & Bebas Heteroskedastisitas \\
& Manajemen Laba & 0.860 & \\
\hline \hline
\end{tabular}

Sumber: Data Diolah

Dari tabel 4 diatas dapat dilihat dari kedua pengujian masing-masing variabel bebas dari gejala heteroskedastisitas. Hal ini ditunjukan dari nilai signifikan yang dihasilkan pada uji Glejser yang lebih besar dari 0,05. 


\section{Analisis Regresi dengan Variabel Intervening}

Tabel 5

Hasil Analisis Regresi Model I

\begin{tabular}{|c|c|c|c|c|c|}
\hline \multirow[t]{2}{*}{ Model } & \multicolumn{2}{|c|}{$\begin{array}{c}\text { Unstandardized } \\
\text { Coefficients }\end{array}$} & \multirow{2}{*}{$\begin{array}{c}\text { Standardized } \\
\text { Coeficients } \\
\text { Beta }\end{array}$} & \multirow[t]{2}{*}{$\mathrm{t}$} & \multirow[t]{2}{*}{ Sig } \\
\hline & $\mathrm{B}$ & Std. Error & & & \\
\hline (Constant) & 7.967 & 2.149 & & 3.708 & .001 \\
\hline Dewan Direksi & -2.025 & 1.095 & -.338 & -1.849 & .073 \\
\hline Komite Audit & -.442 & 1.200 & -.067 & -.368 & .715 \\
\hline
\end{tabular}

Dependent Variabel : Manajemen Laba

Sumber: Data SPSS

Tabel diatas merupakan hasil regresi berganda dari model I, dewan direksi mempunyai koefisien regresi sebesar $-0,338$ hal ini menunjukan dengan peningkatan jumlah dewan direksi sebesar 1 orang maka manajemen laba akan mengalami penurunan sebesar 33,8\%. Dan untuk komite auidit koefisien regresi yang dihasilkan sebesar -0,067 hal ini menunjukan dengan peningkatan jumlah komite audit sebesar 1 orang maka manajemen laba akan mengalami penurunan sebesar 6,7\%. Dengan asumsi variabel lain dianggap konstan.

Tabel 6

Hasil Analisis Regresi Model II

\begin{tabular}{|c|c|c|c|c|c|}
\hline \multirow[t]{2}{*}{ Model } & \multicolumn{2}{|c|}{$\begin{array}{l}\text { Unstandardized } \\
\text { Coefficients }\end{array}$} & \multirow{2}{*}{$\begin{array}{c}\text { Standardized } \\
\text { Coeficients } \\
\text { Beta } \\
\end{array}$} & \multirow[t]{2}{*}{$\mathrm{t}$} & \multirow[t]{2}{*}{ Sig } \\
\hline & B & Std. Error & & & \\
\hline (Constant) & -.870 & .399 & & -2.182 & .033 \\
\hline Dewan Direksi & .163 & .045 & .420 & 3.615 & .001 \\
\hline Komite Audit & .129 & .079 & .187 & 1.630 & .108 \\
\hline Manajemen Laba & 3.304 & .000 & .001 & .009 & .993 \\
\hline
\end{tabular}

Dependent Variabel : Kinerja keuangan

Sumber: Data SPSS

Tabel diatas merupakan hasil regresi berganda dari model II, hasil yang ditunjukan dari analisis regresi ini adalah koefisien regresi dewan direksi sebesar 0,420 yang menunjukan dengan peningkatan jumlah dewan direksi sebesar 1 orang maka kinerja keuangan akan mengalami peningkatan sebesar 42\%. Dan untuk koefisien regresi variabel komite audit sebesar 0,187 menunjukan bahwa dengan peningkatan jumlah komite audit sebsar 1 orang maka kinerja keuangan akan mengalami peningkatan sebesar $18,7 \%$. Serta untuk variabel manajemen laba koefisien regresi yang dihasilkan sebesar 0,001 hal ini menunjukan dengan peningkatan tindakan manajemen laba sebesar $1 \%$ maka kinerja keuangan akan mengalami peningkata sebesar $0,1 \%$.

\section{Analisis Jalur}

Analisis jalur digunakan untuk menguji pengaruh variabel intervening (mediasi). Analisis jalur merupakan perluasan dari analisisi regresi untuk menaksir hubungan tidak langsung antar satu variabel melalui variabel mediasi. Dari nilai-nilai yang dihasilkan 
pada kedua model regresi yang dilakukan, maka diperoleh diagram jalur sebagai berikut:

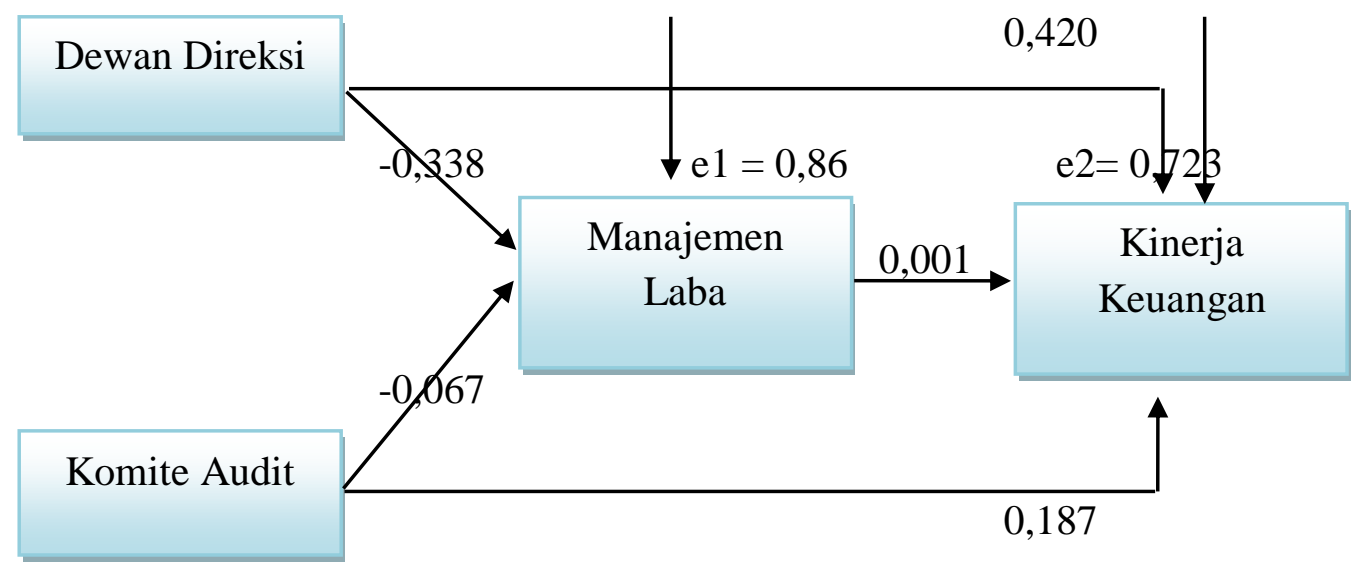

\section{Gambar 1 \\ Diagram Jalur Model}

Dari diagram jalur yang dihasilkan dapat dilihat bahwa masing-masing variabel memberikan pengaruh langsung terhadap variabel kinerja keuangan, dimana 0,420 adalah pengaruh langsung yang diberikan dewan direksi terhadap kinerja keuangandan 0,187 adalah pengaruh langsung yang diberikan komite audit terhadap kinerja keuangan. sedangkan untuk pengaruh tidak langsung diperoleh dengan perkalian antara pengaruh langsung dewan direksi rehadap manajemen laba dengan pengaruh langsung manajemen laba terhadap kinerja keuangan. dan sebaliknya.

\section{Uji Hipotesis}

\section{Uji T (Parsial)}

Dari tabel hasil regresi model I dapat dilihat nilai t yang dihasilkan dari variabel dewan direksi adalah sebesar -1,849 dengan nilai signifikan 0,073 dan dibandingkan dengan t-tabel sebesar 1,66757 nilai t-hitung variabel ini lebih kecil, sehingga disimpulkan bahwa dewan direksi berpengaruh negatih dan tidak signifikan terhadap manajemen laba. Sedangkan untuk variabel komite audit nilai t yang dihasilkan adalah sebesar -0,368 dengan nilai signifikan sebesar 0,715 dan t-tabel 1,66757. Hasil ini menunjukan bahwa komite audit berpengaruh negatif dan tidak signifikan terhadap manajemen laba.

Dari table hasil regresi model II dapat dilihat nilai t yang dihasilkan variabel dewan direksi adalah sebesar 3.615 dengan nilai signifikan 0,001. Dan jika dibandingkan nilai t-hitung dengan t-tabel, nilai t-hitung dewan direksi ini lebih besar dari nilai t-tabel sehingga disimpulkan secara parsial dewan direksi berpengaruh positif dan signifikan terhadap kinerja keuangan. Dimana untuk nilai t-tabel yang digunakan disini adalah 1,66757, nilai t-tabel ini dilihat dari tabel-t dengan sampel sebanyak 68 (70-2) dan presentase 5\% (0,05). Untuk variabel komite audit nilai t-hitung yang dihasilkan adalah sebesar 1.630 dengan nilai signifikan sebesar 0,108. Dan dibandingkan dengan t-tabel sebesar 1,66757 nilai t hitung lebih kecil sehingga 
disimpulkan bahwa komite audit berpengaruh positif dan tidak signifikan terhadap kinerja keuangan. Untuk variabel manajemen laba nilai t-hitunga yang dihasilkan 0,009 dengan nilai signifikan 0,993. Dan dibandingkan dengan t-tabel nilai t hitung lebih kecil sehingga disimpulkan bahwa manajemen laba berpengaruh positif dan tidak signifikan terhadap kinerja keuangan.

\section{Sobel Test}

Uji Sobel digunakan dalam melakukan pengujian hipotesis mediasi. Uji Sobel dilakukan dengan cara menguji kekuatan pengaruh tidak langsung variabel Independen ke variabel dependen melalui variabel mediasi. Dari tes sobel yang dilakukan nilai $\mathrm{t}$ hitung yang dihasilkan sebesar -0,3086 lebih kecil dari t tabel dengan tingkat signifikansi 0,05 yaitu sebesar 1,66757 , hal ini menunjukan bahwa koefisien mediasi tidak signifikan yang berarti tidak ada pegaruh mediasi. Dengan demikian disimpulkan bahwa manajemen laba tidak memediasi hubungan antara dewan direksi dengan kinerja keuangan.

Untuk Komite audit nilai t hitung yang dihasilkan dari tes sobel sebesar -0,05583 lebih kecil dari t tabel dengan tingkat signifikansi 0,05 yaitu sebesar 1,66757, maka koefisien mediasi tidak signifikan yang berarti tidak ada pegaruh mediasi. Dengan demikian dapat disimpulkan bahwa manajemen laba tidak memediasi hubungan antara komite audit dengan kinerja keuangan.

\section{Pembahasan}

Hasil regresi menunjukan bahwa variabel dewan direksi berpengaruh positif dan signifikan terhadap kinerja keuangan. Dengan demikian hipotesis pertama yang menyatakan dewan direksi berpengaruh positif dan signifikan terhadap kinerja keuangan diterima. Penelitian ini mendukung penelitian sebelumnya dari Dewi (2012) yang menunjukan pengaruh positif dan signifikan dari variabel dewan direksi terhadap kinerja keuangan. Hasil penelitian ini bertentangan dengan Widyati (2013) yang menunjukan hasil tidak signifikannya pengaruh dari dewan direksi tersebut terhadap kinerja keuangan. Dengan semakin banyaknya dewan direksi dalam perusahaan maka kinerja keuangan akan semakin bagus. Selain itu dewan direkksi juga mempunyai wewenang dalam menentukan kebijakan yang akan diambil perusahaan baik jangka pendek maupun jangka panjang.

Variabel komite audit berpengaruh positif dan tidak signifikan terhadap kinerja keuangan. Sehingga hipotesis komite audit berpengaruh negatif dan tidak signifikan diterima. Hasil ini mendukung penelitian Widyati (2013) yang menemukan hasil bahwa komite audit berpengaruh positif tidak signifikan terhadap kinerja keuangan. Hasil ini bertentangan dengan Lestari (2011) yang membuktikan bahwa komite audit berpengaruh positif dan signifikan terhadap kinerja keuangan.Dengan adanya komite audit pada perusahaan maka laporan keuangan perusahaan diharapkan dapat lebih berkualitas sesuai dengan tanggung jawab daan tugas dari komite audit tersebut. Namun dilihat dari hasil hipotesis diatas dapat disimpulkan bahwa jumlah komite audit dalam perusahaan tidak mampu menjamin keefektifan kinerja dari komite audit dalam melakukan tugas dan pengawasannya terhadap kinerja keuangan perusahaan (Widyati 2013). 
Variabel dewan direksi berpengaruh negatif dan tidak signifikan terhadap manajemen laba. Hipotesis ketiga yang menyatakan dewan direksi berpengarih positif dan signifikan terhadap manajemen laba ditolak. Hasil penelitian ini berbeda dengan penelitian sebelumnya oleh Iqbal \& Fachriyah (2016) yang menemukan hasil bahwa dewan direksi berpengaruh positif dan signifikan terhadap manajemen laba. Pengaruh yang tidak signifikan ini menunjukan jumlah dewan direksi dalam perusahaan tidak menjamin berkurangnya tindakan manajemen laba dalam perusahaan tersebut. hal ini dikarenakan dewan direksi tidak melakukan fungsi pengawan terhadap praktek manajemen laba, dimana fungsi pengawasan ini hanya dilakukan oleh dewan komisaris independen dan komite audit saja.

Komite audit mempunyai pengaruh yang negatif dan tidak signifikan terhadap kinerja keuangan perusahaan. Dengan demikian hipotesis yang menyatakan komite audit berpengaruh negatif terhadap manajemen laba diterima. Hasil ini konsisten dengan penelitian Kusumaningtyas (2012) yang menemukan hasil bahwa komite audit berpengaruh terhadap manajemen laba secara negatif. Hasil ini juga diperkuat oleh Agustia (2013) yang menemukan hasil bahwa pengaruh komite audit yang ditujukan kepada manajemen laba tidak signifikan. Karena tidak signifikannya pengaruh yang diberikan, maka komite adit tidak terlalu berpengaruh terhadap manajmen laba. Hal ini dapat dilihat dari peraturan Bapepam yang menyatakan bahwa pembentukan komite audit dalam perusahaan dilakukan hanya untuk memenuhi ketentuan pihak pemerintah saja. Hal ini juga ditunjukan oleh penunjukan anggota komite audit yang tidak didasarkan pada kompetensi dan kapabilitas yang memadai sehingga kinerja dari komite audit ini tidak optimal dan kurang efektif serta tidak terlalu berpengaruh.

Manajemen laba mempunyai pengaruh yang positif dan tidak signifikan terhadap kinerja keuangan. Dengan demikian hipotesis lima ditolak. Penelitian ini sesuai dengan penelitian Afnan (2014) yang menunjukan hasil bahwa manajemen laba memberikan pengaruh yang positif dan tidak signifikan terhadap kinerja keuangan. Serta diperkuat dngan penelitian Ujiyantho, Arief\& Agus (2007) yang membuktikan bahwa manajemen laba mempunyai dampak yang tidak signifikan terhadap kinerja keuangan.

Dari pengujian Sobel yang dilakukan, pengaruh mediasi yang dihasilkan tidak signifikan yang berarti tidak ada pengaruh mediasi. Hal ini menunjukan bahwa manajemen laba tidak memediasi hubungan dewan direksi dengan kinerja keuangan. Dengan demikian hipotesis keenam ditolak.

Untuk variabel komite audit pengaruh mediasi yang dihasilkan juga tidak signifikan hal ini menunjukan manajemen laba tidak memediasi hubungan dari komite audit dengan kinerja keuangan. Secara teoritis fungsi pengawasan serta pengendalian yang dilakukan komite audit terhadap tindakan manajemen laba mempunyai hubungan positif, hal ini ditunjukan dengan berkurangnya tekanan manajer terhadap komite audit dalam penyusuan laporan keuangan. Penelitian Sriwedari (2012) yang hanya menguji pengaruh langsung dari masing - masing variabel menunjukan hasil komite audit berpengaruh positif tidak signifikan terhadap manajemen laba dan manajemen laba berpengaruh negatif tidak signifikan terhadap kinerja keuangan. 


\section{SIMPULAN}

Dari hail pengujian hipotesis yang telah dilakukan mengenai pengaruh dari variabel dewan direksi dan variabel komite audit terhadap kinerja keuangan dengan dimediasi (variabel intervening) oleh manajemen laba, maka ditarik kesimpulan sebagai berikut : Dewan direksi berpengaruh positif dan signifikan terhadap kinerja keuangan, Komite audit berpengaruh positif dan tidak signifikan terhadap kinerja keuangan, Dewan direksi berpengaruh negatif tidak signifikan terhadap manajemen laba, Komite audit berpengaruh negatif tidak signifikan terhadap manajemen laba, Manajemen laba berpengaruh positif dan tidak signifikan terhadap kinerja keuangan dan Manajemen laba tidak memediasi hubungan antara dewan direksi dengan kinerja keuangan serta Manajemen laba tidak memediasi hubungan antara komite audit dengan kinerja keuangan.

\section{UCAPAN TERIMAKASIH}

Selesainya penelitian ini penulis banyak mendapatkan bantuan dan dorongan baik secara moril, maupun spritual, oleh karena itu penulis ingin menyampaikan rasa terimakaih yangsebesar besarnya kepada: Bapak Febryandhie Ananda, SE.,M.Si selaku ketua STIE "KBP" Padang, Ibu Lidya Martha, SE, MM selaku ketua STIE "KBP" Padang, Ibu Febsri Susanti selaku ketua program studi Manajemen, Ibu Aminar Sutra Dewi, SE.,M.Si selaku pembimbing yang telah bersedia meluangkan waktu membimbing dalam penulisan penelitian ini, Ibu Maria Magdalena selaku penasehat akademik program studi manajemen dan kepada semua pihak yang telah banyak membantu penulis yang tidak bisa penulis sebutkan satu persatu.

\section{DAFTAR PUSTAKA}

Afnan, A. (2014). Pengaruh Ukuran Dewan Komisaris , dan Proporsi Komisaris Independen Terhadap Kinerja Keuangan dengan Manajemen Laba Sebagai Variabel Intervening.

Agustia, D. (2013). Pengaruh Faktor Good Corporate Governance , Free Cash Flow , dan Leverage Terhadap Manajemen Laba, 15(1), 27-42. https://doi.org/10.9744/jak.15.1.27-42

Danil, A., \& Yusra, I. (2019). Pengaruh kausal antara ukuran perusahaan, nilai buku dan likuiditas saham di Bursa Efek Indonesia. INA-Rxiv.

Dewi, A. S. (2012). Pengaruh Corporate Governance dan Laverage Terhadap Kinerja Keuangan pada Perbankan yang Terdaftar di BEI. Kajian Akuntansi Dan Auditing, $7(1), 61-71$.

Ghozali, I. (2011). Aplikasi Analisis Multivariate dengan Program IBM SPSS 20 (6th ed.). Semarang: Universitas Diponegoro.

Hadya, R. (2013). Pengaruh Harga dan Risiko Saham Terhadap Likuiditas Saham Pada Perusahaan-Perusahaan Yang Terdaftar Di Bursa Efek Indonesia. Jurnal KBP, $1(2), 208-231$.

Hadya, R., Begawati, N., \& Yusra, I. (2017). Analisis Efektivitas Pengendalian Biaya, 
Perputaran Modal Kerja, dan Rentabilitas Ekonomi Menggunakan Regresi Data Panel. Jurnal Pundi, 01(03), 1-35.

Hadya, R., \& Susanto, R. (2018). Model hubungan antara keberagaman gender, pendidikan dan nationality dewan komisaris terhadap pengungkapan corporate social responsibility. Jurnal Benefita, 3(2), 149-160.

Husni, R. (2010). Pengaruh Mekanisme Good Corporate Governance, Leverage dan Profitabilitas terhadap Manajemen Laba, 2008-2011.

Iqbal, S., \& Fachriyah, N. (2016). Corporate Governance sebagai ALat Pereda Praktik Manajemen Laba (Earning Management). TEMA.

Kusumaningtyas, M. (2012). Pengaruh Independensi Komite Audit dan Kepemilikan Institusional terhadap Manajemen Laba, 9(1), 41-61.

Lestari, E. (2011). Pengaruh Good Corporate Governance Terhadap Kinerja Keuangan.

Noviawan, R. A. (2013). Pengaruh Mekanisme Corporate Governance dan Struktur Kepemilikan terhadap Kinerja Keuangan.

Putra, A. D., \& Yusra, I. (2019). Peran profitabilitas dalam memoderasi pengaruh free cash flow terhadap kebijakan dividen di Indonesia. INA-Rxiv.

Sekaredi, S. (2011). Pengaruh Corporate Governance terhadap Kinerja Keuangan Perusahaan.

Sriwedari, T. (2012). Mekanisme Good corporate governance, Manajemen Laba dan Kinerja Keuangan Perusahaan Manufaktur di Bursa efek Indonesia, 4, 78-88.

Sugiyono. (2015). Statistik Nonparametris untuk penelitian (Bayu Rahma).

Sulistyanto, S. (2014). Manajemen Laba (Teori dan Model Empiris). (A. Listyandarari, Ed.). Jakarta: PT Gramedia Widiasarana Indonesia.

Ujiyantho, A., \& Bambang, A. (2007). Mekanisme Corporate Governance, Manajemen Laba, dan Kinerja Keuangan, (6), 1-26.

Utomo, A. (2014). Pengaruh Mekanisme Good Corporate Governance terhadap Kinerja Keuangan.

Widiawati, H. (2011). Pengaruh Corporate Governance terhadap Kinerja Keuangan ( Studi Empiris pada Perbankan di Bursa Efek Indonesia ).

Widyati, M. F. (2013). Pengaruh Dewan Direksi, Komisaris Independen, Komite Audit, Kepemilikan Manajerial Dan Kepemilikan Institutional Terhadap Kinerja

Keuangan. Jurnal Ilmu Manajemen, 1(1), 234-249.

Yusra, I. (2016). Kemampuan Rasio Likuiditas dan Solvabilitas dalam Memprediksi Laba Perusahaan: Studi Empiris pada Perusahaan Telekomunikasi yang Terdaftar di Bursa Efek Indonesia. Jurnal Benefita, 1(1), 33-42. https://doi.org/http://dx.doi.org/10.22216/jbe.v1i1.878 
